\title{
JUDICIAL REVIEW OF ACTS OF CONGRESS AND THE NEED FOR CONSTITUTIONAL REFORM
}

\section{CHARLES GROVE HAINES $\dagger$}

I

CONSTITUTIONAL law has its roots so deeply imbedded in the past

that it is impossible to consider the delicate and intricate adjustments which have, resulted therefrom and with which some of the foremost issues of national politics are now concerned without reference to some of the steps in its continuous growth. Citations in recent opinions of the views of Hamilton, Madison, Monroe and Story refer again to the fundamental divergences of opinion in early American constitutional interpretation. ${ }^{1}$ Jefferson, who attached little in the way of special sanctity to rules formulated in written parchments, favored a generous use of the power of amendment and a thorough revision of the constitution for each generation. Once drafted and formally enacted, however, it was Jefferson's view that the constitution's terms and conditions should be strictly and literally followed until necessary and desirable changes could be secured through amendments. Hamilton, on the other hand, who would have preferred to have government operate without written restrictions, when called upon to interpret such restrictions favored a loose or latitudinarian interpretation of national authority to be attained in large part through a doctrine of implied or resulting powers. ${ }^{2}$ Had Hamilton's wish been followed, the federal government would have been granted extensive powers to regulate matters in the interest of the general welfare. When the Convention failed to adopt his plan, Hamilton suggested a way of accomplishing the same result through the spending power of Congress. Commenting, in his report to Congress on manufactures, on the grant of authority to Congress to lay and collect taxes with only a few express limitations, he contended that

"the power to raise money is plenary and indefinite, and the objects to which it may be appropriated are no less comprehensive than the payment of the public debts, and the providing for the common defence and general welfare. ... There seems to be no room for 'a doubt, that whatever concerns the general interests of learning, of agriculture, of manufactures, and of commerce, are within the sphere of the national councils, as far as regards an application of money." 3

† Professor of Political Science, University of California, Los Angeles.

1. See especially opinion of Justice Roberts in United States v. Butler, 56 Sup. Ct. 312 (1936), and dissenting opinions of Justice McReynolds in Norman v. B. \& O. Rr. Co, 294 U. S. 240 (1935), and Justice Sutherland in Home Building and Loan Ass'n v. Blaisdell, 290 U. S. 298 (1934).

2. III THE WORKS OF ALEXANDER HaMntion (Lodge ed. 1885-86) 458.

3. IV Id. at 151, 152. 
Madison took issue both with Hamilton's doctrine of implied powers and his extensive application of the idea of national control over matters of general interest. Instead, Madison formulated a theory of federalism whereby "different parts of the same instrument ought to be so expounded as to give meaning to every part," and insisted that the more doubtful and indefinite terms of the written charter, such as the general welfare clause could not be so interpreted and expanded that the clear and precise expressions in the grants of power to Congress would be denied any real significance. ${ }^{*}$ Thus, Jefferson and Madison insisted that, to maintain the federal balance the position of the states, as well as that of the federal government, must be preserved. The general welfare clause or the phrases approved in the Convention authorizing federal control of national interests or of affairs wherein the states were separately incompetent were thus held to be limited to mere interpretation or enlargement of the grants of power expressly allotted to the federal government by the Constitution.

As is well known, the procedure outlined by Thomas Jefferson was not approved. Instead, Congress and the Supreme Court, particularly under the leadership and direction of Chief Justice Marshall, adopted the Hamiltonian method of expanding federal authority through the medium of a doctrine of implied powers. Though the principle that the Constitution established a dual system of government, with state and federal powers delicately balanced as Madison insisted, was frequently reiterated, it came gradually to be assumed that if a power normally belonged to a sovereign government, and if it was desirable for the purpose of taking care of the political or economic needs of the nation during an emergency, the necessary authority for federal exercise of the power could be found among the ends expressly granted to the federal government in the Constitution and the means which might be deemed appropriate to carry such powers into effect. ${ }^{5}$

With the Civil War confirming the supremacy of the federal government by force of arms, the Supreme Court in the Legal Tender Decisions adopted outright the Hamiltonian-Marshall principle that in accomplishing the ends granted to the federal government in the Constitution a "national government with sovereign powers" was created and that it was possible to use any means which Congress might deem appropriate

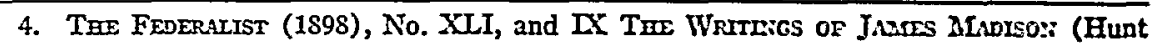
Ed. 1910), 411 ff.

5. For cases containing expressions of this view, see American Insurance Co. v. Canter, 1 Pet. 511, 541 (U. S. 1S28); Legal Tender Cases, 12 Wall. 457, 529ff. (U. S. 1870); Kohl v. United States, 91 U. S. 367, 371 (1S75); Norman v. Baltimore \& Ohio Rr. Co., 294 U. S. 240 (1935). In the light of the prevailing point of view in a variety of cases, Justice Holmes observed in Missouri v. Holland, 252 U. S. 416, 433 (1920) that "it is not lights to be assumed that in matters requiring national action, a power which must belong $t$, and somewhere reside in every civilized government, is not to be found." 
provided that the particular power was not expressly prohibited. ${ }^{\circ}$ In other words, instead of following the precept of the Tenth Amendment, which Jefferson regarded as fundamental, namely, that all powers not granted to the federal government are reserved to the states or to the people, it was assumed that, if occasion demanded, the federal government might in connection with its rather extensive grant of powers exercise any authority it desired, limited only by the few express prohibitions found in the Constitution. This line of reasoning, adopted on important occasions both by Congress and by the Supreme Court, was carried to its logical conclusion in the dictum of President Theodore Roosevelt and Senator Elihu Root to the effect that, if any, field could advantageously and appropriately be regulated by the federal government, such authority should be assumed and supported by the necessary interpretations and constructions of the Constitution. ${ }^{7}$ President Roosevelt frankly stated that he approved the assumption that it was his duty to do what the general welfare of the country required, and that, in doing so, he was limited only by the express prohibitions on the exercise of federal powers. ${ }^{8}$

The failure to accept the Jeffersonian principle calling for rather literal interpretation of the written fundamental law and its regular and systematic amendment to meet the changing conditions and needs of the country had serious and largely unforeseen consequences on the growth of constitutional law. A type of constitutional exegesis or legal theology developed, which has been one of the chief features of American political life. Events have verified Viscount Bryce's comment that a written fundamental law which does not provide adequately for its growth from within must grow or secure its flexibility from without. Hence the policy of interpreting the words of the Constitution to secure certain political ends, of discovering "Iatent and unsuspected meanings" from its sphinx-like terminology, of giving expression to the silences of the Constitution, or of the application of the Alice-in-Wonderland device of having words mean one thing today and another tomorrow. But the theory and practice which gave encouragement and sanction to the

6. McCulloch v. Maryland, 4 Wheat. 316, 404-407 (U. S. 1816); Knox v. Lce, 12 Wall. 457 (U. S. 1871); Juillard v. Greenman, 110 U. S. 421 (1884). "If it is an appropriato means" . . said Chief Justice Hughes, "the decisions of the Congress as to the degreo of necessity for the adoption of that means, is final." Norman v. B. \& O. Rr. Co., 294 U. S. 240,311 (1935).

7. "Federal governmental power should be increased through executive action ... and through judicial interpretation and construction of law." From address of Presldent Theodore Roosevelt at Harrisburg, Pa., October 4, 1906. "Sooner or latcr constructions of the Constitution will be found to vest additional power in the national government," from address of Elihu Root before Pennsylvania Society in New York, December 12, 1906.

8. Opinion quoted in Willtars Howard Taft, The Presidency: Its Duties, Its Powers, ITs OpPORTUNITIEs, AND ITs LINTTATIONS (1916) 125, 126. 
justices for the expansion of federal powers by interpretation, also predicated a basis for the restriction of these powers by a doctrine of implied limitations. Chief Justice Marshall and Justice Story indicated the possibilities in the way of checking the exercise of national powers through implied limitations ${ }^{3}$ but no attempt was made to apply such limitations until the last two decades of the nineteenth century. Supreme Court justices have, therefore, not only become adept in marping legal terms to secure results desirable in their view of public policy, but they have also acquired a rather disturbing facility in discovering limitations on legislative and executive powers in the general and indefinite phrases to be found in the Constitution.

\section{II}

It was the adoption of the practice of the review of legislation by the courts, however, which, when coupled with the Hamiltonian method of changing the document by interpretation, gave to constitutional exegesis its peculiar American stamp and developed the express and implied limitations of the Constitution. In making such limitations effective, judicial review has changed its base from its original mooring as a jurisdictional equilibrator in the application of the theory of the separation of powers and in the adjustment of federal relations, to that of the guardian of the fundamental ideas and premises of conservatism in political and economic affairs. European commentators familiar with the evolution of American constitutional law, such as Professor Edouard Lambert of the University of Lyon have regarded the change of judicial review from a jurisdictional function in the maintenance of the balance of powers among the departments and between state and federal authorities to a form of censorship over the wisdom or expediency of legislative or administrative action both of state and federal officers, particularly with reference to the regulation of social and economic affairs, as a movement of major importance in the course of American constitutional interpretation. ${ }^{10}$ This change, accomplished by reading new meaning and content into phrases such as due process of law and equal protection of the laws, by reviving and giving more extensive scope to the theory of separation of powers, and when the specific or general language of the written constitution was lacking, by falling back on the spirit of written

9. See Marshall's opinion in Fletcher v. Peck, 6 Cranch 87, 135, 139 (U. S. 1810); Justice Story's views in Territt v. Taylor, 9 Cranch 43, 52 (U. S. 1815), and Willinson v. Leland, 2 Pet. 627, 658 (U. S. 1829); also, argument of Webster in Dartmouth College v. Woodward, 4 Wheat. 518, 581 (U. S. 1819).

10. LE GOUVERAEJIENT DES JUGES ET LA LUTTE CONTRE LA IfGLSLATIO:i SOChLLE AUX:

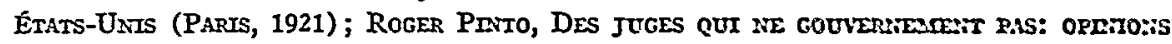
DISSTEENTES A LA COUR SUPREATE des ÉTATS-UNIS (1900-1933) 1934. 
constitutions or on the nature of free government, built up what Duguit, Hauriou and Lambert have called a veritable super-constitution. ${ }^{11}$

With the determination to exert authority both over federal and state legislation unqualifiedly asserted in the last decades of the nineteenth century, the federal courts joined the state courts in declaring a large number of state and federal legislative acts void. So aroused did public opinion become, as a result, that the curtailment of judicial authority was made an issue in national and state politics under the leadership of Theodore Roosevelt and Robert M. LaFollette. Yet, even after the decision of the Supreme Court of the United States in Lochner v. New York ${ }^{12}$ it could still be argued, as was done by Charles Warren in $1913,{ }^{13}$ that the attitude of the Supreme Court toward social and industrial legislation was in the main a progressive one. But beginning with the period following the World War, a change has come and the cases in which the court has found objections to legislative policies under the due process, taxation, commerce, and general welfare clauses give the unmistakable impression that the court now looks upon itself as the first line of defense against what is regarded as dangerous socialization of political and economic life. The general summary of acts held void by the Supreme Court shows the significant change in the attitude of the justices toward legislation. With only two cases declaring acts unconstitutional in the first seventy five years of the operation of federal government in the United States, and forty cases in the last thirty years, some of these involving major governmental measures designed to aid the process of recovery from an industrial depression, it is apparent that the function of the judiciary with respect to the review of acts of Congress has become essentially obstructive. ${ }^{14}$ The extension of the regulative functions of state and federal governments accounts in part for a larger percentage of acts being declared void, but by no means accounts for or justifies the present unusual mortality rate of statutes passed upon by the Court, or the change from a procedural or jurisdictional type of review to one which becomes a directive and controlling factor in the field of substantive law.

11. Cf. Hannes, The Revival of Natural Law Concepts (1930) 206ff., $260 f$ f.

12. 198 U. S. 45 (1905).

13. The Progressiveness of the United States Supreme Court (1913), 13 CoL. I. REv. 294.

14. Summary of Cases Declaring Acts of Congress void.

$1789-1864-2$ cases in 75 years

1864-1885-16 cases in 21 years

1886-1906-12 cases in 20 years

1906-1924-23 cases in 19 years

1924-1935-17 cases in 11 years

1789-1906-30 cases in 116 years 1906-1935-40 cases in 30 years. 
III

Appraisal of the system of judicial review of acts of Congress may best be made upon the bases of a résumé of the decisions through which the Supreme Court has invalidated acts or parts of acts of Congress. Despite the fact that the principle of judicial review was announced in 1803, the doctrine of legislative supremacy prevailed in the federal government for nearly seventy years. The pronouncement of Chief Justice Marshall in Marbury v. Mladison ${ }^{10}$ served, as Jefferson suggested, as nothing more than an intimation to justices in future cases that they might refuse to enforce a congressional enactment which they considered in conflict with provisions of the Constitution. For three decades the Supreme Court used its prestige and authority to strengthen the national government and to restrict some of the extreme notions of state sovereignty. For two decades more, it aimed to hold an even balance between federal and state agencies. Not until the Court, under Chief Justice Taney, made its mistake in the Dred Scott Case ${ }^{16}$ in 1857 in declaring the Missouri Compromise Act void, did the issue as between legislative supremacy and the right of the courts to serve as a check upon the political departments of the government became a vital matter in federal politics. And for the next twenty years, though the Court undertook on various occasions to assert its supremacy over both Congress and the President in the interpretation of the Constitution, when occasion arose the President and Congress ignored both the Constitution and the Court to carry out policies deemed essential to the national welfare. With the exception of the Dred Scott Case the first issue of major importance involving the validity of an act of Congress, was raised in the Civil Rights Cases in 1883.17 Judicial supremacy, though asserted at various times as a principle of the federal Constitution, may be considered largely, then, as a development of the last few decades of the nineteenth century, so far as its rôle in limiting the exercise of federal authority is concerned.

This fact has significance. For the control of the courts over the Constitution took shape in the era of rising industrialism, of the development of large corporations and not infrequently monopoly control, of the beginning of the regulative efforts of the state and federal governments over the commerce and industry of the nation, and of the insistence of the dominant business interests, with the approval of both major political parties, that the economic and political doctrine of laissez faire must at all hazards be sustained. The transformation of the balance of power in the federal system took place in the era to which

15. 1 Cranch 137 (U. S. 1803).

16. Scott v. Sanford, 19 How. 393 (U. S. 1857).

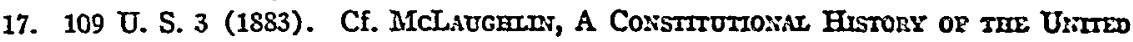
States (1935) 317, 318. 
Justice Holmes referred ${ }^{18}$ when men, fearing they could not control legislatures, turned to the courts for the discovery of principles either within or outside of the constitutions to condemn policies which the business interests of the country disapproved.

There are approximately seventy cases in which acts of Congress or portions of acts were declared void. These may be grouped roughly under such headings as cases affecting the jurisdiction of the courts, acts which encroached on the powers of the states or interfered with individual rights, and limitations on the taxing powers.

Of the cases in which the court declined to accept jurisdiction conferred upon it by Congress, only one is of any special importance in the development of federal law, namely, Marbury v. Madison, ${ }^{10}$ and the significance of this case has been exaggerated. At the time the decision was rendered, the law establishing the office, for the attainment of which a mandamus was sought, had been repealed; so that the judgment in effect was rendered in a moot case. The case, however, afforded an appropriate opportunity for the announcement of the Federalist doctrine of judicial review of legislation and the supremacy of the judiciary in constitutional interpretation, if for no other purpose than as a warning to the Jeffersonian Democrats. The refusal of the Court in Muskrat v. United States to give an advisory opinion to. Congress interfered with a practice which, with judicial review of legislation as an established feature of the Government, might have had a wholesome effect in permitting the determination in advance of difficult issues of constitutional law. ${ }^{20}$ If the Supreme Court had been called upon and expected to render an advisory opinion regarding the constitutionality of the National Industrial Recovery Act and of the Agricultural Adjustment Acts at the time of their enactment, is it not probable that the decisions arrived at would have been different from those announced in 1935 and 1936 , and that the framing of a permanent national policy relating to commerce and industry would have been facilitated?21

In approximately a score of cases the Court held that Congress had enacted measures which encroached on the powers of the states. It is noteworthy that the first instance of this kind arose in 1870, almost one hundred years after the adoption of the Constitution, when Congress attempted to fix a standard for the sale of petroleum oil. ${ }^{22}$ With but

18. Collected Legal Papers (1921) 184.

19. 1 Cranch 137 (U. S. 1803).

20. Muskrat v. United States, 219 U. S. 346 (1911).

21. It would seem just as probable, however, in other situations, that advisory oplnions would result in voiding statutes which, had they come before the Court at a later date and after experience in their practical application, might have been sustained. [Editor's note.]

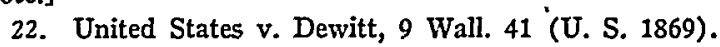


two exceptions, the significant decisions of the Supreme Court thus far had sustained the exercise of authority by the federal government and had condemned state action which was thought to interfere with federal authority. At about the same time as the decision in the oil standard case, objections to attempts to tax the income of state officers and the interest from municipal bonds were invalidated. ${ }^{23}$ Here, as well as in some earlier instances involving the state taxation of federal agencies, the Court might have applied the doctrine, that only discriminatory or unreasonable types of taxes interfering with state or federal agencies were subject to condemnation. This would have permitted the uniform and non-discriminatory application of tax laws to subjects now having an unwarranted exemption from taxation-a plan which federal systems such as Canada and Australia have adopted after having discarded Chief Justice Marshall's reasoning on the doctrine of implied prohibitions.

A series of six of the decisions in this group relate to the Civil War Amendments to the Constitution and to the attempts of Congress to regulate political and civil rights within the states. The Supreme Court refused to approve the efforts to carry out the general policy of the Northern Reconstruction leaders to change the federal relationships so as to nationalize the control over civil rights."2

With the exception of a few cases of minor import the remaining decisions in this category related to the control over foreign and domestic commerce. Though there are only a few such cases, they are of outstanding significance. Congress, it was held, could not regulate trademarks or employers' liability when the regulation was not confined to foreign and interstate commerce, ${ }^{25}$ nor could interstate shipment of goods produced by child labor be prohibited. ${ }^{20}$ In what portends to be a new era in constitutional interpretation, the National Industrial Recovery $\mathrm{Act}^{27}$ and the Railroad Retirement Act ${ }^{23}$ were held not pertinent to the regulation of interstate commerce, and the Agricultural Adjustment Act was condemned as interfering with the reserved rights and powers of the states. ${ }^{29}$ After one hundred years of the approval and application, with only a few outstanding exceptions, of a policy of nationalism through the doctrine of implied powers, the Supreme Court

23. Collector v. Day, 11 Wall. 113 (U. S. 1871); United States v. Railroad Co., 17 Wall. 322 (U. S. 1873).

24. United States v. Reese, 92 U. S. 214 (1876); United States v. Harris, 106 U. S. 629 (1883); Civil Rights Cases, 109 U. S. 3 (1883); Baldwin v. Franks, 120 U. S. 678 (1887); James v. Bowman, 190 U. S. 678 (1903); Hodges v. United States, 203 U. S. 1 (1906).

25. Trade Mark Cases, 100 U. S. 82 (1879); Employers' Liability Cases, 203 U. S. 1 (1908).

26. Hammer v. Dagenhart, 247 U. S. 251 (1918).

27. A. L. A. Schechter Poultry Corporation v. United States, 295 U. S. 495 (1935).

28. Railroad Retirement Board v. Alton Rr., 295 U. S. 330 (1935).

29. United States v. Butler, 56 Sup. Ct. 312 (1936). 
has decided to apply a local, provincial, and implied prohibition doctrine by means of the commerce and due process of law clauses of the Constitution and of the limitations of the Tenth Amendment.

Although not applied to any significant extent until the Income Tax Cases, ${ }^{30}$ limitations on the powers of Congress to levy taxes now loom as among the foremost grounds, exceeding the phrase "due process of law," for restricting the authority of Congress. Beginning with the notable decisions of 1895 which necessitated the constitutional amendment of 1913, the court condemned three laws as involving stamp taxes on exports ${ }^{31}$ and then refused to permit the taxation of net income on stock dividends despite the amendment to the Constitution which $\mathrm{Mr}$. Justice Holmes regarded as designed to put an end to meticulous quibbling as to the meaning of income in federal taxation..$^{32}$ Income taxes on federal judges' salaries ${ }^{33}$ and a tax on the net profits of manufacture to prohibit child labor were also annulled. ${ }^{34}$ Despite the Court's previous policy of approving federal tax laws obviously designed for purposes of regulation ${ }^{35}$ three acts of Congress in this category met with disapproval on the ground that they were primarily enacted for regulative purposes. ${ }^{36}$ But the most significant trend of the decisions in tax cases came with the application of the due process clause of the Fifth Amendment $^{37}$ and the Marshall doctrine ${ }^{38}$ of implied prohibitions. ${ }^{39}$

30. Pollock v. Farmers Loan and Trust Co., 157 U. S. 429 (1895), rehearsing, 158 U. S. 601 (1895).

31. Fairbanks v. United States, 181 U. S. 283 (1901); United States v. Hvoslef, 237 U. S. 1 (1915); Thames and Mersey Ins. Co. v. United States, 237 U. S. 19 (1915).

32. Eisner v. Macomber, 252 U. S. 189 (1920).

33. Evans v. Gore, 253 U. S. 245 (1920); Booth v. United States, 291 U. S. 339 (1934).

34. See Bailey v. Drexel Furniture Co., 259 U. S. 20 (1922).

35. Champion v. Ames, 188 U: S. 321 (1903); McCray v. United States, 195 U. S. 27 (1904).

36. Child Labor Tax Case, 259 U. S. 20 (1922); Lipke v. Lederer, 259 U. S. 557 (1922); Hill v. Wallace, 259 U. S. 44 (1922). For a discussion as obiter dicta on the limits applicable to Congress in using the taxing power as a regulative device, sce Justice Roberts' opinion in United States v. Butler, 56 Sup. Ct. 312 (1936).

37. Nichols v. Coolidge, 274 U. S. 531 (1927); Untermeyer v. Anderson, 276 U. S. 440 (1928) (holding retroactive tax provisions void); Heiner v. Donnan, 285 U. S. 312 (1932) (declaring invalid $\S 302$ (c) of the Revenue Act of 1926 creating a conclusive presumption that gifts made within two years prior to the death of the donor were made in contemplation of death and requiring the value of such gifts to be included in computing the valuo of the net taxable estate); Lynch v. United States, 292 U. S. 571 (1934) (preventing taxation of policies of yearly renewable term insurance issued under the War Risk Insurance Act, on the ground that contracts of the United States would thereby be breached).

38. See McCulloch v. Maryland, 4 Wheat, 316, 425ff. (U. S. 1819).

39. National Life Insurance Co. v. United States, 277 U. S. 508 (1928) (holding void portions of $\S 213$ of the Revenue Act of 1921, taxing the gross income of insurance companies in so far as it was applied to the income from state and municipal bonds); Indian 
The encroachments upon individual rights to which the Supreme Court objected related primarily to the protection of vested rights ( 3 cases), the guarding of jury trial ( 5 cases), and claims that due process of law was violated (4 cases), and one each under the following phrases or provisions of the Constitution,-ex post facto law, unreasonable searches and seizures, protection against self-incrimination, admission of improper evidence, and interference with individual privileges. Though the Court in interpreting the constitutional provisions protecting individual rights veered in the direction of the narrow or common law interpretation of the procedural requirements of the Constitution, only a few of these cases involved matters of serious or vital concern to citizens. The method of securing evidence for conviction of offenses under federal laws was made more difficult than is the practice under corresponding procedural rules in the states. ${ }^{40}$ The federal government was required to pay the value of a franchise in eminent domain proceedings to condemn a toll bridge. 11 Congress in its war-time control of the necessaries of life was denied authority to impose penalties without making the nature of the offense specific. ${ }^{22}$ But the outstanding decision in this group condemned the minimum wage law of the District of Columbia and inferentially rendered void similar state laws. ${ }^{13}$

On the other hand, the Court did not protect either citizens or aliens from what was deemed by many to be an unreasonable and unduly oppressive Espionage Act. It has not prevented the executive from suspending the writ of habeas corpus ${ }^{44}$ or instituting a blockade ${ }^{45}$ contrary to express provisions of the Constitution and of thereby establishing a veritable "state of siege" so far as individual rights are concerned, when a condition of war is imminent or in progress. Though the guarantees in favor of individual liberty are occasionally invoked to protect the utterance of liberal or even radical views, such instances of judicial protection to individual rights are so rare as to be negligible. As a rule,

Motocycle Co. v. United States, 283 U. S. 570 (1931) (preventing the cnforcement of $\S 600$ of the Revenue Act of 1924 in so far as an attempt was made to apply it to the sale of motorcycles to a municipal corporation); Burnet v. Coronado Oil and Gas Co., $285 \mathrm{U}$. S. 393 (1932) (holding void a tax on a lease to a private company for the extraction of gas and oil from lands granted to the state for the use of its public schools).

40. Boyd v. United States, 116 U. S. 616 (1886); Counselman v. Hitchcodi, 142 U. S. 547 (1892).

41. Monongahela Navigation Co. v. United States, 14S U. S. 312 (1893).

42. United States v. L. Cohen Grocery Co., 255 U. S. 81 (1921).

43. Adkins v. Children's Hospital, 261 U. S. 525 (1923).

44. Cf. the efforts of Chief Justice Taney to prevent President Lincoln from suspending the writ of habeas corpus without a prior grant of such authority from Congress. MIcPherson, The Polmital History of the United Stites or Azrrici durmig mie Great REBErTION (1876) 154.

45. See approval of Lincoln's order establishing a blockiade of Southern ports, Prize Cases, 2 Black. 635 (U. S. 1862). 
legislative and executive interferences with individual rights have met with the Court's approval. The emotional appeal to support judicial review of acts of Congress which centers around the preservation of the sacred and inalienable individual rights has a slender basis in the Court's record to date.

Decisions holding that Congress could not adopt the workmen's compensation laws of the state ${ }^{46}$ or that Congress could not limit the authority of the President to remove officers, ${ }^{47}$ the latter now considerably restricted by a subsequent pronouncement, ${ }_{1}^{8}$ tended only slightly to affect the authority of Congress.

It is contended that, since the court has found so few acts of Congress to condemn during a century and a half, ${ }^{40}$ there is little ground for apprehension if Congress be allowed more extensive powers. It is claimed by others, however, that Congress has frequently been deterred from passing acts because of the belief that they would be declared void by the courts. But although the probability that acts were likely to meet with judicial disapproval has no doubt served as a deterrent factor in relation to certain legislative proposals, the importance of such a check may readily be exaggerated. The strikingly few instances in which legislatures violate the provisions of written constitutions where legislative supremacy prevails indicates that legislators normally take as seriously their duties and responsibilities in regard to the support and protection of the written fundamental law as do the judges.

Even if all of the decisions in which the Supreme Court held acts of Congress invalid were correctly decided, there has been a distinct loss in removing from active public discussion and determination certain vital issues of national policy. For, over against the advantages gained by deferring to the judiciary on important issues of public authority except when an extraordinary wave of public sentiment assures a reversal by constitutional amendment, is the fact that the people lose the political experience and education, as well as the social stimulus that comes from facing an issue and coming to grip with its determination. Though the popular decision may be wrong, the experience gained in its discussion and determination results in a useful and provocative exchange of ideas and in the strengthening of the political fibre. This is the doctrine that Justice Holmes advocated in and out of the sessions of the Court, namely, that it is desirable to permit the people through their authorized political agencies to experiment in the field of political and economic regulation,

46. Knickerbocker Ice Co. v. Stewart, 253 U. S. 149 (1920).

47. Myers v. United States, 272 U. S. 52 (1926).

48. Humphrey's Exec. v. United States, 295 U. S. 602 (1935).

49. It is estimated that 24,300 public laws were enacted by Congress from 1789 to 1936 and that less than 65 separate acts were declared void. See the U. S. News, Jan. 20, 1936. 
regardless of whether the experimentation may seem to many individuals to be reasonable or advantageous.

Some of the apparent weaknesses and defects of judicial nullification of acts of Congress may be illustrated by a consideration of the reasoning and the implications of recent decisions. By a series of judicial pronouncements the federal courts, following the reasoning and dicta in certain state cases, changed the meaning of due process of law from a procedural limitation, applicable primarily to methods of apprehending, trying and condemning individuals for alleged criminal acts, to a limitation applicable to legislative and executive acts, when from the point of view of judges they appeared unreasonable or arbitrary. This change of interpretation of the most significant phrase in the Fifth and Fourteenth Amendments has been so frequently and fully considered that it need not be elaborated upon for present purposes. ${ }^{\text {.0 }}$ It is not an exaggeration to state, however, that this judicial extension of the meaning of due process of law converted judicial review of legislation into a form of corrective quite different from that prevailing heretofore and had a far-reaching effect on many phases of constitutional interpretation. The new version of due process of law gave sanction for the judicial condemnation of labor laws, ${ }^{51}$ of retroactive provisions in federal tax laws, ${ }^{52}$ of railroad pension legislation ${ }^{53}$ and of the attempt of Congress to grant relief to a certain class of debtors. ${ }^{5 t}$ It renders applicable as a test for all federal laws the concept of reasonableness, which involves a variety of connotations and furnishes legal sanction for the consideration of the wisdom or expediency of legislation. It was the application of this test to state enactments, now held as a necessary standard for all federal acts, which led Justice Holmes to raise a protest a few years before he resigned from the bench, that "as the decisions now stand I see no limit but the sky to the invalidating of those rights [of the states under the

50. Cf. my article, Judicial Review of Legislation in the United States asd the Doctrine of Vested Rights and of Implied Limitations on Legislatures (1924) 3 TEx. L. REv. 1, and monograph on The Rerrval of Naturax Law Coxcepts (1930) cc. V-VITI; aleo, Corwin, The Doctrine of Due Process of Law Before the Civil War (1911), 24 Hasv. L. Rev. 366, 460. Reference to this change was made by Mr. Justice Brandeis in Whitncy v. Callifornia, 274 U. S. 357, 373 (1926) when he said: "Despite arguments to the contrary which had seemed to me persuasive, it is settled that the due process clause of the Fourteenth Amend. ment applies to matters of substantive law as well as to matters of procedure."

51. Lochner v. New York, 198 U. S. 45 (1903) (ten-hour law in balkerics); Adkins v. Children's Hospital, 261 U. S. 525 (1923) (minimum wage haw for District of Columbia).

52. Nichols v. Coolidge, 274 U. S. 531 (1927).

53. Railroad Retirement Board v. Alton Rr., 295 U. S. 330 (1935).

54. Louisville Joint Stock Land Bank v. Radford, 55 Sup. Ct. 869 (1935). 
Fourteenth Amendment] if they happen to strike a majority of this court as for any reason undesirable."

\section{Spending Power}

There is no provision in the federal Constitution that a tax shall be for a public purpose and few provisions of such import are found in the state constitutions. ${ }^{56}$ The notion that a tax may be levied for a public purpose only, however, was formulated by the state justices about the middle of the nineteenth century to place a curb on the trend toward extravagant governmental appropriations. ${ }^{57}$ But restrictions upon such forms of public expenditure were frequently prohibited by amendments to the state constitutions. Justice Miller, in a case relating to an issue of bonds to build a factory, asserted on behalf of the Justices of the Supreme Court of the United States, that the requirement of public purpose was a foundation principle of all constitutional government. Judge Cooley, who contended in People v. Salem" that "all governmental powers exist for public purposes" had stated as a dictum in his Constitutional Limitations that "taxation having for its only legitimate object the raising of money for public purposes, and the proper needs of government, the exaction of moneys from the citizens for other purposes is not a proper exercise of this power and must therefore be unauthorized." ${ }^{160}$ The judicial construction of implied tax limitations on the legislature was progressing so rapidly that Cooley ventured to assert in 1879 that "... whatever differences of opinion may exist regarding the admissibbility of taxation in particular cases, the fundamental requirement, that the purpose must be public, will be conceded on all sides." ${ }^{\prime \prime}$

55. Baldwin v. Missouri, 281 U. S. 586, 595 (1930).

56. For a summary note relating to such constitutional provisions, see McAllister, Public Purpose in Taxation (1930) 18 Calre. L. Rev. 138.

57. Speaking for the majority of the Supreme Court of Pennsylvania in Sharpless v. The Mayor of Philadelphia, $21 \mathrm{~Pa} .147,168$ (1853), upholding the authority of the legislature to empower city officials to subscribe to and sell bonds to finance the purchase of the stock of railroads, Chief Justice Black said that, the general grant of legislative power did not include authority to raise funds for a private purpose, for "taxation is a mode of raising revenue for public purposes. When it is prostituted to objects in no way connected with the public interests or welfare, it ceases to be taxation and becomes plunder." For an earlier formulation of the public purpose doctrine by Chancellor Kent of New York see Gardner v. Newburgh, 2 Johns Ch. 162, 166 (N. Y. 1816).

58. Loan Association v. Topeka, 20 Wall. 655 (U. S. 1874).

59. 20 Mich. 452,478 (1870).

60. 1868 edition, at 487,488 . See also opinion of Chief Justice Dillon of Iowa in Hanson v. Vernon, 27 Iowa 28, 43 (1869).

61. Coorey on Taxation (1st ed. 1881) 67. In his Constitutionat, Immitations (8th ed. 1927), Cooley stated his political philosophy, which he was diligently trying to translato into constitutional law, as follows: "There is no rule or principle known to our system undor which private property can be taken from one man and transferred to another for tho private use and benefit of such other person, whether by general laws or special cnactment. 
Following the reasoning of Cooley and Dillon, the public purpose principle as implied from the inalienable rights clause of the bill of rights or the due process of law and eminent domain provisions of state constitutions was held to prevent the taking of the property of a citizen for a private use.

Transferring these dicta to the realm of federal jurisprudence was a process which apparently was making headway rather slowly ${ }^{62}$ until Justice Roberts interpolated into the language of the federal Constitution a new form of the public purpose principle that "the word [tax] has never been thought to connote the expropriation of money from one group for the benefit of another." 03 By this dictum an amendment to the Constitution is in process of formulation which may change to a considerable degree the functions exercised by the federal government. Are not by this reasoning all forms of aid to individuals indulged in by Congress from the beginning of the government, including numerous tariff acts, pension laws, aid to sufferers from flood or drought, as well as relief measures of every type, and a considerable variety of taxes levied by the federal government, subject to serious constitutional infirmities? Or will the Supreme Court Justices in future cases shrink from the exercise of the extravagant form of judicial censorship foreshadowed in such a dictum?

\section{Separation and Delegation of Powers}

Through the presumed requirements of the principle of the separation of powers, ${ }^{64}$ with the correlative principle that the legislature cannot delegate its functions to any other agency, new and unwarranted criteria of judicial review of congressional acts are being aimed at still other legislative and executive exercises of power. Justice Cardozo in his concurring opinion in the decision in the N.R.A. Case speaks of the dangers

The purpose must be public, and must have reference to the needs of government." As indicative of the trend in the states, see Lowell v. Boston, 111 MIass. 454 (1873), condemning an issue of bonds for the purpose of making loans to individuals for rebuilding homes burned in the Boston fire, and opinion of Chicf Justice Appleton upholding an injunction to prevent the town of Jay from making a loan to secure a sawmill and a box factory. This, said the Chief Justice, is "communism incipient, if not perfected." Allon v. Inhabitants of Jay, 60 Me. 124 (1872).

62. In Jones v. City of Portland, 245 U. S. 217 (1917) the Supreme Court tool: jurisdietion to determine whether under the due process clause of the Fourteenth Amendment taxes levied to operate a fuel yard were levied for a public purpose, but in this case as in Green v. Frazier, 253 U. S. 238 (1920), involving experiments in the field of industrial enterprise by the State of North Dakota, and in City of Boston v. Jackson, 260 U. S. 309 (1922), concerning an expenditure of public money to aid a publicly operated subway system, the members of the Court could see no violations of the public purpose prineiple.

63. United States v. Butler, 56 Sup. Ct. 312, 317 (1936).

64. See Panama Refining Co. v. Ryan, 293 U. S. 385 (1935) ; A. L. A. Schechter Poultry Corp. v. United States, 295 U. S. 495 (1935). 
involved in "unconfined and vagrant power" and objects to "a roving commission to inquire into evils, and upon discovery correct them." No definite or even approximate standard has been provided, he states, to which legislation must conform. Reference is made to ethical or commercial standards that can be known or predicted in advance, which were lacking in the act of Congress. ${ }^{65}$ But is it not apparent that many of the so-called standards which legislatures have laid down for administrative agencies, now as a rule approved by the courts, are in the nature of general orders in exceedingly vague terms and which become concrete under the direction of the administration both in the determination of standards and in their application ${ }^{60}$ The requirement in health laws that the premises be kept in a sanitary condition, in workmen's compensation provisions that factories be rendered safe for employees, in insurance acts that a company be reliable and entitled to public confidence, and in rate regulation that undue preference be not granted to shippers, - these and a variety of other general phrases directed to administrative officers, frequently included in statutes and usually approved by the courts, mean no more than the frequent admonition in the interstate commerce acts that the Commission should determine a question "as in its judgment the public interest demands," or that it should sanction only arrangements which are "just and reasonable." In all of these instances the legislature authorizes and instructs administrative officers to formulate standards and to lay down rules for the guidance of individual conduct and it is the enforcement of such rules with the experience gained thereby which gives form and content to the purpose expressed by the legislature. It was this sort of administrative action which Circuit Judge Learned Hand had in mind when he said, in relation to the National Industrial Recovery Act: "The phrase 'fair competition' seems to me a definite enough cue or ground plan for the elaboration of a code." 68

It is a rather strange procedure for the members of the Supreme Court to express much concern regarding the fear of determination of matters by coordinate departments of the government in accordance with vague phrases involving "vagrant" powers, especially since the chief charge

65. A. L. A. Schechter Poultry Corp. v. United States, 295 U. S. 495, 551 (1935).

66. See, e.g., authority granted to Secretary of War to remove structures regarded as "unreasonable obstructions" to navigation, approved in Union Bridge Co. v. United States, 204 U. S. 364 (1907); power of Secretary of Labor to deport aliens who are "undesirablo residents" of the United States, approved in Mabler v. Eby, 264 U. S. 32 (1924), and authority of Secretary of Agriculture to prescribe "just and reasonable" commissions for livestock brokers, approved in Tagg Bros. \& Morehead v. United States, 280 U. S. 420 (1930).

67. N. Y. Central Securities Corp. v. United States, 287 U. S. 12 (1932). For similar phrases of a discretionary nature consult Searfacan, The Interstate Comouence Comainssion: A Study in Admentstrattve Law and Procedure (1931) part II, 357 ff.

68. United States v. Schechter Poultry Corporation, 76 F. (2d) 617, 624 (1935). 
against the Supreme Court in many of its decisions under the due process of law and equal protection of the laws clauses of the Fifth and Fourteenth Amendments is that these phrases are in no sense standards and that the Court has nevertheless exercised by means of them for many years an effective censorship over social and economic legislation, acting as a kind of "House of Lords" for both the federal and state governments. ${ }^{69}$ It would seem that the real "vagrant and unconfined" power in the American system of government is that of the courts acting as censors of legislative and executive acts. All other departments and agencies of governments are subject to regular and effective checks when their acts must be justified before the bar of public opinion. ${ }^{30}$ The courts alone can give final judgments whether in accordance with standards or no standards; and as far as the Supreme Court of the United States is concerned, a full and effective accounting before the people, due to the extreme difficulty of amending the Constitution, may be deferred for a generation or more.

The Court in recent decisions gives the impression that it is confined by the inexorable logic of the written constitution which it is charged to interpret. Justice Roberts, in the majority opinion of the $A . A . A$. Case stated:

"It is sometimes said that the court assumes a power to overrule or control the acts of the people's representatives. This is a misconception. The Constitution is the supreme law of the land ordained and established by the people. All legislation must conform to the principles it lays down. When an act of Congress is appropriately challenged in the courts as not conforming to the Constitutional mandate, the judicial branch of the government has only one duty, to lay the article of the Constitution which is invoked beside the statute which is challenged and to decide whether the latter squares with the former. All the court does or can do is to announce its considered judgment upon the question. The only power it has, if such it may be called, is the power of judgment. This court neither approves nor condemns any legislative policy. Its delicate and difícult

69. Albert M. Kales called attention to this phase of judicial review in 1918 when he observed that: "In addressing the Court in due process cases one should not commence with the usual salutation 'may it please the court', instead one should say, 'Ary Lords: Backed by and charged with the enforcement of the due process clause of the Fifth and Fourteenth Amendments, the Supreme Court of the United States is the Ameriean substitute for the British House of Lords. It constitutes the real and only concervative second chamber of the federal government. It is a second conservative chamber for each of the state governments. . . . Like all conservative second chambers the Supreme Court and the due process clause are in a hopeless dilemma." New Blethods in Due-Process Cases (1918) 12 Axr. Pox. Sar. Rev. 241. Cf. also Sayre, Dinumum Wage Decision: Hows the Sufreme Court becomes virtually a House of Lords (May 1, 1923) 50 Sonver 150-151.

70. An "unconstitutional exercise of power by the executive and legislative branches of the government is subject to judicial restraint," said Justice Stone, whereas "the only checl: upon our own exercise of power is our own sense of self-restraint." Dissenting opinion in United States v. Butler, 56 Sup. Ct., 312, 325 (1936). 
office is to ascertain and declare whether the legislation is in accord with or in contravention of the provisions of the Constitution, and having done that, its duty ends."

This language is reminiscent of the mechanical approach to the law of the late eighteenth and early nineteenth centuries when judicial review of legislation was in process of formulation. ${ }^{72}$ Though repeated at various times by justices inclined toward a mechanistic approach to the law, ${ }^{73}$ its fallacies have been so frequently exposed by the "realistic" and "sociological" jurists" that it takes considerable temerity to repeat the statement today as an inescapable truism.

The dissenting justices, speaking through Justice Stone, scarcely give this "juristic ritual" or "legal mythology", as Frank calls it, respectful consideration. In a sharply worded and caustic opinion the majority are impliedly at least charged by the minority with overstepping their judicial duty and of sanctioning a tortured construction of the Constitution which leads to curtailment of the powers of Congress by "judicial fiat." What is made to appear as an application of the rule of law or the plain and simple operation of the doctrine of ultra vires conceals an issue which is more fundamental, namely, by what standard is legislative and administrative action to be approved or condemned by justices who are conceded as having for most purposes the final judgment as to its validity. With such phrases as due process of law and general welfare as guides, or with the demarcation of powers as national or state where governmental functions necessarily overlap, the decision is made on the basis of the conscious or unconscious assumption of the social desirability of certain consequences and a judgment is rendered that is presumed to promote those consequences. ${ }^{75}$ When such indefinite standards are applied by justices "accustomed to believe that it is the business of courts to sit in judgment on the wisdom of legislative action,"

71. United States v. Butler, 56 Sup. Ct. 312,318 (1936). For a similar view as to tho detached attitude of Justices in considering the validity of legislation, compare comments of Justice Roberts in Railroad Retirement Board v. Alton Ry. Co., 295 U. S. 330 (1935).

72. Cf. Pound, Mechanical Jurisprudence (1908) 8 CoL. L. REv. 605; and state decisions, Grimball v. Ross, T. U. P. Charlt. 175, 178 (Ga. 1808); Byrne v. Stcwart, 3 Des. 466,477 (S. C. 1812 ).

73. See similar opinion by Justice Sutherland in Massachusetts v. Mellon, 262 U. S. 447, 488 (1923).

74. See Jerome Frank, Law and THE Modern MTND (1930), and Are Judges Human? (1931) 80 U. of PA. L. REv. 17, 231; Llewellyn, A Realistic Jurisprudence (1930) 30 Cot. L. Rev. 431, and The Constitution as an Institution (1934) 34 Cox. L. Rev. 1; Powell, The Judiciality of Minimum Wage Legislation (1924) 37 Harv. L. Rev. 545. For a comparison of the "mechanical theory" and the theory of "free legal decision," see my article, Gencral Observations on the Effects of Personal, Political, and Economic Influences in the Decisions of Judges (1922) 17 ILL. L. REv. 96.

75. Walter Wheeler Cook, on Legal Methods in the FIFTH ConfEREnce of Trachers or INTERNATIONAL LAW (1933) 56. 
it is timely for honored and respected members of the highest tribunal to remind their brethren and the people of the nation that "courts are not the only agency of government that must be assumed to have the capacity to govern."76

In reality, the rigid limitations which the Court interprets and applies in order to rebuke sternly the legislative and executive departments, are largely judge-made limitations read into the Constitution by justices who looked with disfavor upon the tendencies toward governmental paternalism and had little respect for popular government as carried out through representatives and executives elected by the people. ${ }^{77}$ An example of such a limitation is apparent in the interpretation of the theory of the separation of powers, now used as a maxim to prevent the delegation of legislative and administrative powers. Though the theory of the separation of powers was formulated and adopted in certain state constitutions beginning in 1776, it is a significant fact that for approximately a century legislative, executive, and judicial powers were frequently mingled in the face of this theoretic division. The legislatures acted as courts of final resort, and in many respects exercised a virtual supremacy over the other departments. They delegated powers freely to executives and at times to courts with only an occasional reversal. Primarily the theory of the separation of powers was used to protect the judiciary from interference with judicial powers by the legislatures and to give aid and sanction to the developing doctrine of judicial review of legislation. ${ }^{73}$ Those responsible for the adoption of the theory of separation of powers as a feature of state and federal constitutional law, asserts Mr. Bondy, were unfamiliar with any supposed possibility of classifying powers according to their intrinsic nature. As understood at the time, the separation theory meant that "any power not expressly vested by the constitution in either of the departments or other governmental authority, irrespective of its nature, may be assumed by the legislature, or delegated

76. From Justice Stone's dissenting opinion in United States v. Butler, 56 Sup. Ct. 312, 329 ff. (1936).

77. "The paternal theory of government," said Justice Brewer, "is to me odious. The utmost possible liberty to the individual, the fullest possible protection to him and his property, is both the limitation and duty of government." Justice Brewer disenting in Budd v. New York, 143 U. S. 517, 551 (1892). Justice Brewer's view later beame the doctrine of the majority of the court. See Chicago, Milwaukee \& St. Paul Ry. Co. v. Minnesota, 134 U. S. 418 (1890); Allgeyer v. Louisiana, 165 U. S. 578 (1897); Lochner v. New York, 198 U. S. 45 (1905); also Justice Peckham's views in In re Jacobs, 98 N. Y. 98 (1885).

78. See comment of Thomas Reed Powell that the theory of the separation of powers so far as the federal government is concerned "becomes through judicial decision a rule of law." Separation of Powers: Administrative Exercise of Legislative and Judicial Pourer (June, 1912) 27 Por. ScI Q. 215. Most of the cases to which Powell refers as giving force to the theory of the separation of powers were decided after 1855 when the courts vere discovering new meanings for due process of law. 
to either of the other departments or any other governmental agency without violating the distributing clause, ${ }^{\prime \prime 9}$ or in the words of Justice Story:

"When we speak of the three great departments of government, and maintain that that separation is indispensable to public liberty, we are to understand the maxim in a limited sense. .... [i.e] the true meaning is that the whole power of one of these departments should not be exercised by the same hands, which possess the whole power of either of the other departments"

and that such exercise of the whole would subvert the principles of a free constitution. ${ }^{80}$ Upon this hypothesis both federal and state governments acted for well nigh a century, following the admonition of Chief Justice Marshall to the effect that

"the difference between departments undoubtedly is, that the legislature makes, the executive executes, and the judiciary construes the law, but the maker of the law may commit something to the discretion of the other departments, and the precise boundary of this power is a subject of delicate and difficult inquiry, into which a court will not enter unnecessarily." 81

It was not until the decades following the Civil War that the state courts, inbued with the spirit of laissez faire economics and politics and therefore seeking grounds to check the growing powers of popular control over political and economic affairs, turned to the theory of separation of powers with the correlative principle of non-delegation of authority ${ }^{82}$ as well as to the due process clause as convenient weapons of attack upon what the judges deemed the exercise of unwise legislative and executive powers. The precept of judicial construction was then announced that the discretionary power, in so far as the carrying out of state functions is concerned, is granted by the theory of separation of powers to the legislature alone, with the executive authority acting in a ministerial capacity. Through numerous court decisions, this judgemade theory has stood in the way of the development of effective administrative methods in the states. Workmen's compensation acts, zoning provisions, control over water rights, the administration of labor laws, social welfare legislation, and other types of public control were nullified by what appeared to many to be unduly restrictive judicial pronouncements based upon the separation of powers theory. Fortunately, the

79. William Bondy, The Separation of Governmental Powers in History, in Theory, and

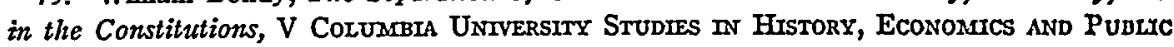
LAW (1896) 210.

80. Comomentartes on the Constitution of the Untred States (5th ed. 1891) 1, 393.

81. Wayman v. Southard, 10 Wheat. 1 (U. S. 1825).

82. For data as to the origin of the latter phase of the theory, consult Duff and Whiteside, Delegata Potestas non Potest Delegari: A Maxim of American Constitutional Law (1929) 14 CoRs. L. Q. 168. 
state legislatures have been freed both by constitutional amendments and by changes in judicial attitudes from many of the shackles construed upon their powers. So marked was the change in this respect that Elihu Root, in a plea for the development of administrative law with a system of effective controls over administrative agencies, observed several decades ago that

"the old doctrine prohibiting the delegation of legislative power has virtually retired from the field and given up the fight. There will be no withdrawal from these experiments. We shall go on; we shall expand them, whether we approve theoretically or not, because such agencies furnish protection to rights and obstacles to wrong-doing which, under our new social and industrial conditions, cannot be practically accomplished by the old and simple procedure of legislatures and courts as in the last generation. ${ }^{83 "}$

Chief Justice Hughes, with the application of a new version of the separation of powers theory in federal jurisprudence, ${ }^{8 *}$ demands for executive action such as that envisaged in the National Industrial Recovery Act a quasi-judicial procedure of the type of the Federal Trade Commission and of the Interstate Commerce Commission with ample provisions "for formal complaints, for notice and hearing, for appropriate findings of fact supported by adequate evidence, and for judicial review to give assurance that the action of the commission is taken within its statutory authority." than to render Congress and the President impotent to deal with the conditions designed to be regulated under the recovery act. It is quite beyond the scope or method of a legislative body to prepare and enact codes of fair business practice for thousands of types of business and industry or even to formulate in general outline the standards to be applied in the formation of such codes. Nor could the President without undue delay and inexpedient limitations of his action follow the procedure of the Federal Trade Commission or the Interstate Commerce Commission in the enforcement of such standards. The primary object of such a holding is, indeed, in the words of the Supreme Court in a previous case relating to the separation of powers, "to stop the wheels of government and bring about confusion, if not paralysis, in the conduct of the public business." ${ }^{286}$ A more reasonable point of view in the light of modern conditions and the requirements of effective public administration was expressed by Circuit Judge Manton who quoted the language of earlier decisions to the effect that

83. Presidential Address before the American Bar Association, (1916) 41 A. B. A. REP. 368, 369.

84. For summary of doctrines applied by the courts in previous cases relative to the delegations of power, see Cousens, The Delegation of Federal Legislative Potter lo Excetstive Officials (1935) 33 MLICH. L. Rev. 512.

85. A. L. A. Schechter Poultry Corporation v. United States, 295 U. S. 495 (1935).

86. Cf. Union Bridge Company v. United States, 204 U. S. 364 (1907). 
"Congress legislated on the subject as far as was reasonably practicable, and from the necessities of the case was compelled to leave to executive officials the duty of bringing about the result pointed out by the statute. To deny the power of Congress to delegate such a duty would in effect amount but to declaring that the plenary power vested in Congress to regulate foreign commerce could not be efficaciously exerted."187

But in this case as well as in the Panama Refining Company Case $e^{\mathrm{sB}}$ the Chief Justice, with his associates approving, apparently gives expression to his feeling of resentment toward the modern tendencies in the development of administrative law. In accordance with previously expressed views ${ }^{80}$ he joins with ardor such critics of recent methods in public administration as the Lord Chief Justice of England, who characterized the modern tendencies in administrative law as The New Despotism, ${ }^{90}$ and Professor Allen of Oxford University who styled the same tendencies as Bureaucracy Triumphant. 01 But a parliamentary investigation instigated by such criticisms found little to condemn in the English practice of delegating broad and significant powers to administrative officers. ${ }^{02}$ The practice of granting the Ministers authority not only to administer but to a large extent to make the law is now a generally approved policy of the English government. ${ }^{33}$

\section{Commerce Power}

In the decisions in the Railroad Retirement and the N.R.A. Cases the Supreme Court interpreted interstate commerce in accordance with the theory of James Madison "that different parts of the same instrument ought to be so expounded, as to give meaning to every part," and that the Constitution and the laws enacted under it must permit both the state and federal governments to function with a reasonable degree of effectiveness and with no undue interference by one division of the government with the functions which are presumed to be allotted to the other. Yet, although in the past the Court has at times followed the limitations applicable to federal powers as envisaged by the Madison federalism doctrine ${ }^{94}$ the interpretations of the Court have more fre-

87. 76 F. (2d) 617,621 (1935).

88. Panama Refining Co. v. Ryan, 293 U. S. 388 (1934).

89. See comments quoted in the N. Y. Times, Feb. 13, 1931 at p. 8; also, Report of Special Committee on Administrative Law (1934) 59 A. B. A. Rep. 200 ff.

90. Lord Hewart, The New Despotism (London, 1929).

91. Carleton Kemp Allen, Bureatucracy Truumpeant (London, 1931).

92. Committee on Ministers' Powers (Donoughmore Committee) presented to Parliament in April, 1932, Cmd. 4060. Cf. Willis, The Pardiascentary Powers of Enolisin DePARTAIENTS (1933) 174 ff.

93. For an account of the growth of delegated legislation in England, consult Wruts, op. cit. supra note 92.

94. Edward S. Corwin has analyzed Madison's notions regarding federalism in Congress' Power to Prolibit Commerce: A Criccial Constitutional Issue (1933) 18 CoRN. L. Q. 477, $481 \mathrm{ff}$. 
quently followed the line of extending the scope and significance of the powers to be exercised under the commerce clause, and of restricting the authority of the states either for purposes of regulation or taxation. Beginning with the decision of Chief Justice Marshall in Brown $v$. Maryland, ${ }^{95}$ it has been made clear that the states are inhibited from any substantial interferences with commerce, and that it is the duty of the federal government to keep the channels of commerce free from obstructions in order to assure its regular and continuous flow.

"The genius and character of the whole government seems to be," as conceived by Marshall, "that its action is to be applied to all the external concerns of the nation, and to those internal concerns which affect the states generally, but not to those which are completely within a particular state, which do not affect other states."

In recent years the Court has tended toward the adoption of the doctrine that not only is the federal government given authority over commerce in a direct sense, but it is also the duty of the federal government to foster and protect commerce so far as it may be disturbed by indirect factors and influences in the states. In Unitcd Mine Workers $v$. Coronado Coal Company ${ }^{\circ 6}$ Chief Justice Taft said:

"It is clear from these cases" that if Congress deems certain recurring practices, though not really part of interstate commerce, likely to obstruct, restrain or burden it, it has the power to subject them to national supervision and restraint."

The Chief Justice was thus affirming a view expressed by Justice Holmes nearly a score of years before when he suggested that Congress had authority to interfere "in cases where such interference is deemed necessary for the protection of commerce among the states." this reasoning, Circuit Judge Manton expressed a view according to which the major features of the National Recovery Administration as well as other phases of recent federal legislation could have been sustained when he observed that "trade practices which, in normal times, would have had only an indirect and incidental effect upon interstate commerce, may substantially burden interstate commerce during a period of overproduction, unfair competition and a reduced purchasing power."99

From yet another point of view, the Court's decision might have been favorable to the exercise of federal powers in both of the above cases.

95. 12 Wheat. 419 (U. S. 1827). 96. 259 U. S. 344, 40S (1922).

97. Citing Swift \& Co. v. United States, 196 U. S. 375 (1905); United States v. Patten, 226 U. S. 525 (1913); United States v. Ferger, 250 U. S. 199 (1919); Railroad Comm. of Wisconsin v. Chicago, B. \& Q. Rr. Co., 257 U. S. 563 (1922); Stafford v. Wallace, 253 U. S. 495 (1922).

98. Swift \& Co. v. United States, 196 U. S. 375, 400 (1905).

99. United States v. Schechter Poultry Corporation, 76 F. (2d) 620 (1935). 
Although the doctrine announced by Chief Justice Jay and accepted by a majority of the Federalists that there is a common law of the United States, was rejected in United States v. Hudson and Goodvoin, ${ }^{100}$ and although the doctrine of the Goodwin Case has been approved many times, nevertheless the doctrine was in effect considerably modified by a series of decisions which followed the Civil War. When Congress began to regulate, with the approval of the courts, lotteries, ${ }^{101}$ the opium traffic, ${ }^{102}$ bills of lading, ${ }^{103}$ and similar transactions coming within the range of commerce, the reasoning was adopted by the Court that transportation of persons or commodities deemed harmful or detrimental to the interests of the public welfare might be regulated by Congress, or, if need be, prohibited from being transported in the channels of commerce. If the desired regulation could not be brought within the range of commerce, steps were taken to attain the same result by' means of prohibitory taxation. By this kind of "covert legislation", as Judge Hough described it, ${ }^{104}$ a type of federal police power became well established as one of the features of the federal system. ${ }^{105}$ The Court called a halt temporarily, at least, to this type of federal control over interstate business in condemning the Child Labor and the Future Trading Acts. ${ }^{100}$

Despite the reasoning in the Child Labor Case, the gradual development of a federal police power over harmful and criminal acts in transactions involving more than one state, along with the principle which the Court on several occasions approved, that acts having an indirect effect on commerce were excepted from control by the states, opened the way for an approval of acts of Congress such as those recently condemned by the Court. Thus, as a result of the growth of the federal police power through the extended application of the commerce clause and the control of state and interstate affairs by means of the taxing power, men began to proceed on the hypothesis that the federal government was authorized, as it was argued in the federal Convention and as the leading Federalists insisted, to legislate when urgent necessity re-

100. 7 Cranch 32 (U. S. 1812).

101. Champion v. Ames, 188 U. S. 321 (1903).

102. United States v. Doremus, 249 U. S. 86 (1919).

103. United States v. Ferger, 250 U. S. 199 (1919).

104. According to Judge Hough, "Congress finally chose the taxing power rather than the postal monopoly as the constitutional support for the regulation of a business almost invariably intrastate and not yet regarded as affected by a public use." Covert Legislation and the Constitution (1917) 30 HARv. L. Rev. 801.

105. For an account of the gradual development of a national police power with the approval of the courts, see Cushman, (Studies in the) Police Power of the National Gov. ernment (1920) 4 Mrov. L. REv. 247 and 402, and (1921) 5 id. at 1.

106. Hammer v. Dagenhart, 247 U. S. 251 (1918); Bailey v. Drexel Furniture Co., 259 U. S. 20 (1922), and Hill v. Wallace, 259 U. S. 44 (1922); but see Board of Trade v. Olsen, 262 U. S. 1 (1923), for approval of a subsequent Grain Futures Act based on the commerce clause. 
quired for the general interests of the United States and to assume those functions concerning which the states are separately incompetent. ${ }^{107}$

That the Supreme Court could have approved the National Industrial Recovery Act by its own reasoning in previous decisions is apparent also when one examines the practice and precedents in relation to the exercise of extraordinary powers to deal with former emergency conditions. If this act is unconstitutional, then various phases of the activities and functions performed by the federal government from 1914 to 1920 were invalid, leaving out of account extreme powers conceded to the legislative and executive departments during previous emergency periods. Powers no less wide, general, and significant were given to President Wilson, Congress having directed him as Commander-in-Chief to win the war, $^{108}$ just as President Roosevelt was directed to promote recovery from some of the disastrous results of an economic depression. May the Court not have held on the basis of reason and precedents that the nation faced an emergency in 1933 as it did in 1916-1917? 109 $^{103}$ Using the Court's own language, "plainly circumstances may so change in time or differ in space as to clothe with such an interest [public] what at other times or in other places would be a matter of purely private concern," or as expressed on another occasion, "a limit in time to tide over a passing trouble may well justify a law that could not be upheld as a permanent one."110 The fact that acts of Congress designed to meet the war emergency and that the wholesale delegation of powers to the President were not opposed by the Courts, has led to the conclusion that "the power of the federal government to prosecute a war is as comprehensive as the needs of the situation demand."

The authority assumed by Congress and the President during the World War and approved by the Supreme Court in several important instances such as the Adamson Labor Act and the acts restricting increases in rents, merely seemed to carry to its logical conclusion a line of reasoning and interpretation which began with Hamilton and which was

107. See Stern, That Connerce Which Concems Ifore States than One (1934) 47 Hurs: L. REv. 1351.

108. "So great were the powers possessed by President Wilson," says Professor Fenwick, "that for the time being his position was one of virtual dictatorship over a wide field covering whatever activities of the people might in the opinion of Congress be made to contribute, whether affirmatively by legislation or negatively by probibition, to the strengthening of the military arm of the government." Poliricir Systers Ii Trurismo:i (1920) 133.

109. President Franklin D. Roosevelt in taking the oath of office said: "I shall acl: the Congress for broad executive power to wage war against the emergency as great as the power which would be given to me if we were, in fact, invaded by a foreign foe."

110. Wilson v. New, 243 U. S. 332 (1917); Block v. Hirsch, 256 U. S. 135 (1921). That the courts may apply a different standard when "an emergency ceaces or the facts change" is recognized in an opinion by Justice Holmes in Chastleton Corporation v. Sinclair, 264 U. S. 543 (1924). 
arriving at the view that, when required by the public interest and the general welfare, any authority which may be necessary to meet an emergency, and the most important powers which are desirable to carry out the ordinary ends of governments in peace time, may be assumed by the federal government without the necessity of amending the Constitution. For it is well to note that the process of expanding federal powers by interpretation to a point at which those things might be satisfactorily regulated which in the judgment of the President and Congress seemed desirable had, with few exceptions, come to be the settled policy of the country, carried out largely by mere interpretations and expansions of the terms and phrases of the federal Constitution.

There were, of course, momentary reactions when the federal courts reminded Congress and the President that the Constitution intended to assure the continuous functioning of a dual system with state and federal governments operating at the same time and that neither could interfere seriously with the activities properly belonging to the other. ${ }^{111}$ But these reactions tended merely to slow down what appeared as the inevitable process of centralization based upon the insistent demands arising from social and economic conditions which, as business, manufacturing, agriculture, and commercial relations generally became national in their essential operations, rendered futile the efforts to retain the force and effectiveness of state boundaries.

For more than forty years after its establishment the Supreme Court conceived its duty and function as requiring the support of the centralizing and nationalistic trends of the time. In a nation building a political and industrial empire the justices adopted principles compatible with progress and expansion. This attitude of "high judicial statesmanship," as it is frequently called, strengthened the judiciary in public esteem and assured its success as the stabilizing force of the government. For the last fifty years, however, the attitude of the justices has been directed to the discovery of limits upon the activities and functions of government. The avenues of public regulations, whether by state or federal action, have indeed been "cabined and confined." The outlook of the justices has been toward the past rather than the future; judicial statesmanship, if such it may now be called, has been devoted mainly to the maintenance of the status quo. At a time, therefore, when the disturbing and destruc-

111. Cf. United States v. E. C. Knight \& Co., 156 U. S. 1 (1895), Hopkins v. United States, 171 U. S. 578 (1898), and Anderson v. United States, 171 U. S. 604 (1898), giving a restricted interpretation to the Sherman Anti-Trust Law which the Court modified in Standard Oil Co. v. United States, 221 U. S. 1 (1911); and Child Labor Cases, supra note 106. For discussion of these and other cases, see Stern, That Commerce Which Affets More States than One (1934) 47 HaRv. L. REv. $1350 \mathrm{ff}$. 
tive elements of industrial life require much greater activity on the part of the legislative and executive agencies of government the courts assume a dog-in-the-manger policy of refusal to permit any government to regulate important phases of social and industrial life. ${ }^{112}$

It has indeed come to pass as Justice White warned that "the governments, state and federal, are bereft by the operation of the Constitution of the United States of a power which must belong to and somewhere reside in every civilized government."113 When it is realized that by present constitutional criteria with their judicial gloss, neither Congress nor the states can fully and effectively regulate traffic, state or interstate, neither Congress nor the states can regulate in any thoroughgoing manner holding companies, pools, and trusts, and neither Congress nor the states can regulate so as to remove conditions deemed generally undesirable and unfair in relation to child labor, unemployment, wages, hours of labor, or prices, the form of political paralysis prescribed by means of the American doctrine of limited government as applied by the courts, becomes apparent.114 The decisions of the Supreme Court of the United States sustaining state emergency acts in the Minnesota Moratorium Case ${ }^{115}$ and the New York Milk Control Case ${ }^{110}$ by 5-to-4 decisions, though indicating a trend toward more liberal criteria for the consideration of legislative acts, have been so interpreted as to affect but little the scope of the field of public regulation.

Judicial review of acts of Congress as well as acts of the states has tended to encourage a form of judicial legislation which has as its chief objective the closing of some of the avenues of public control except so far as judicial decisions may be reversed by the cumbersome process of constitutional amendments. It has made of the Supreme Court one of the foremost legislative agencies of the nation. But its legislative activities are exercised for the most part in a negative and destructive man-

112. "What we face now, at numerous and critical points," says Dean Garricon, "is the question, not how governmental functions shall be shared, but whether in substance we shall govern at all," in The Constitution and the Future (Jan. 29, 1936) New Repunuc 328.

113. Andrews v. Andrews, 188 U. S. 15, 32 (1903).

114. "It has never been supposed, since the adoption of the Constitution," said Chicf Justice Taft, "that the business of the butcher, or the baker, the tailor or the wood chopper, the mining operator or the miner was clothed with such a public interest that the price of his product or his wages could be fixed by state regulation." Wolfi Pacling Co. v. Industrial Court, 262 U. S. 522, 537 (1923). See also decisions condemning other state regulatory acts-Fairmont Creamery Co. v. Minnesota, 274 U. S. 1 (1926) (regulating prices for buyers of cream); Williams v. Standard Oil Co., 278 U. S. 235 (1927) (prescribing prices for sale of gasoline); New State Ice Co. v. Liebmann, 285 U. S. 262 (1932) (controlling the manufacture and sale of ice).

115. Home Building \& Loan Ass'n v. Blaisdell, 290 U. S. 398 (1934).

116. Nebbia v. New York, 291 U. S. 502 (1934). 
ner. ${ }^{117}$ And judicial legislation in the field of constitutional law is subject to the same infirmities which characterized this phase of the court's work in the growth of the common law. Though the justices are influenced by the beliefs and feelings of the time, they are more likely to be guided by the professional habits and ways of thinking of the groups with which they normally associate. Furthermore they are more likely to be interested in the logic and symmetry of the law than in the objects and policies to be attained through the law. ${ }^{118}$ It is rather to be expected that the Justices would not look favorably upon new legislative ventures and would seek to find limits to governmental powers other than those expressly defined in the Constitution.

Judges have frequently pointed out, as did Chancellor Kent, that justices may decide what is just and expedient and then seek the precedents to sustain their action. This observation is peculiarly applicable to certain phases of constitutional interpretation. It is apparent, both from the language of the Court and from its general attitude, that an unfavorable judgment was formed regarding recent acts of Congress and that that reasoning was then adopted which would sanction the view formed. The Court appears to have ignored its own well-recognized attitude in interpreting the Constitution as a document designed to establish "a government for a nation." No more discouraging and disheartening situation could be imagined than the present demoralization of federal administration due to the lack of agreement, understanding and coöperation between the legislative and executive departments of the government and the judiciary.

It may be taken for granted that under the stress of circumstances mistakes and misjudgments were made both in the enactment of legislation and in its administration. But such mistakes as were made were not due to the lack of understanding of the meaning and significance of the Constitution. Eminent authorities on constitutional law could find ample justification for the acts passed, both in the express language of the document and in its amplification by judicial construction. The present disastrous results of judicial review of legislation in the American federal system can lead to only one conclusion, namely, that if a

117. "To annul a law," said Professor Hans Kelsen, "is to establish a general norm; for the abolition of a law has" (the same) "character of generality as to make it, being, so to speak, only the making with negative action-hence a phase of the legislative function. $A$ court ... which has the power to annul laws is consequently an organ of legislative power." La garantie juridictionnelle de la constitution (1928) 45 Revue DU Drorr PunLXC 197. For certain modifications in the practice and procedure relating to judicial review, based on the notion that this function of the courts is essentially legislative in character, sce Grant, Judicial Review under the Austrian Constitultion of 1920 (1934) 28 Axr. Pox. Scr. Rxv. 670 ff.

118. Dicey, Lectures on the Relation between law and Publac Opinion in EnoLAND dURING the NInEteente Century (1905) 361. 
government adequate to meet the exigencies of modern industrial society is desired, the legislative and executive departments of the government must be given authority to deal with emergencies and to carry out the will of the people..$^{119}$

If interstate commerce is limited in accordance with the criteria announced by the Court in the Railroad Retirement and N.R.A. Cases, and the taxing and spending powers of Congress are confined within the restrictions imposed by the $A . A . A$. decision, a broad interpretation of federal authority has definitely been rejected and the Constitution has become an instrument unsuited to the economic and social conditions of modern life. "Powers not granted are prohibited. None to regulate agricultural production is given," maintained Justice Roberts in the A.A.A. Case, "and therefore legislation by Congress for that purpose is forbidden."120 Thus the word "expressly" is added to the language of the Tenth Amendment, the word which Chief Justice MIarshall insisted was not inserted in the amendment when he declined to adopt the views of Jefferson and approved instead the dictum of Hamilton in the following words, quoted in Justice Stone's dissenting opinion:

"Iet the end be legitimate, let it be within the scope of the Constitution and all means which are appropriate, which are plainly adapted to that end, which are not prohibited, but consistent with the letter and spirit of the Constitution, are constitutional."121

After more than a century of liberal construction, following Alexander Hamilton's formula as developed by Chief Justice Marshall and his successors, with so few exceptions as not seriously to check the main trend of constitutional interpretation, the government of the United States is, by a series of Court decisions, held to be confined within limits similar to those advocated by Thomas Jefferson. Thus, it is demanded that we live within the confines of the Constitution, both as placed there by express language and as implied by judicial construction, until it can be duly amended, regardless of the effect upon the nation. With such a restrictive interpretation, however, it must be remembered that Thomas Jefferson favored frequent amendments to the Constitution and a total revision, at least for each generation. A constitution which can-

119. "No great nation," asserts Harold J. Laski, "with problems to solve commensurate with its greatness will submit the control of its policy to a majority of pine men who can not be called to account for their actions. Where fundamental disharmony of this lind persists, the time has come for constitutional revision." In review of Coswris Tre TwrIIGert of THE Suprease CourT (1935) 44 YaLE L. J. 1126.

120. MIajority opinion in United States v. Butler, 56 Sup. Ct. 320 (1936).

121. MicCulloch v. Maryland, 4 Wheat. 316, 421 (U. S. 1816). See Tae Wosws or AtexANDER HaArITON (Lodge ed. 1885-36) 458. 
not be expanded by interpretation or readily amended to meet the conditions of a modern economic and industrial society must either be discarded or in many respects subjected to rather drastic revision.

The modernized version of the Jefferson-Madison doctrine to which the Supreme Court appears now to be committed means that there can be no consistent national planning along either economic or political lines, that progress in the carrying out of national policies can only be by fits and starts, that periods of forward movement will be followed by periods of political paralysis when the wheels of government must stand still while new paths to meet the wishes of our legal conservators are being formulated. Such a condition points to the conclusion that either the present Constitution must be revised so that adequate powers may be granted to the federal government to deal with those conditions for which the states are separately incompetent and some of the shackles which now fetter state action must be removed, or steps must be taken to secure a form of national legislative supremacy.

There is no doubt that the time has come to give serious consideration to the calling of a Constitutional Convention-though it be a long deferred one, when viewed according to the Jeffersonian standard. All who desire to see a system of government adequately organized to cope with the complex problems of modern life must look forward to the early calling of a National Constitutional Convention. ${ }^{122}$

For the most part excepting certain obsolete sections the present provisions of the Constitution could be retained, with special efforts, however, to remove some of the checks and balances which were deliberately inserted in the Constitution to prevent free and effective action. More definite arrangements should be provided for the coöperation of the legislative and executive departments. Significant changes are necessary along the line of the increase of federal powers. Authority should be given to the federal government to regulate commerce, industry and business, both state and interstate, so far as is necessary to carry out national policies. The federal government should be given authority to secure uniform control over crime and criminal procedure, as well as authority to develop standards and secure uniformity in the field of social and economic legislation. Ways should be devised also for the extension of regional planning, both in the organization and administration of government. It is significant to note that the proposal to increase the powers of the federal government accords with the constitutional provisions and the practice of other federal systems of government. ${ }^{123}$

122. In The Need for Constitutionad Reform (1935), Professor W. Y. Elliot presents cogent arguments for thorough constitutional revision with interesting and suggestive pro. posals for consideration by such a convention.

123. Authority is granted to the national government of Argentina to enact civil, commercial, penal and mining codes and "to provide for all that conduces to the prosperity of 
Primary consideration will need to be given to the removal of the checks and the paralysis of political activity resulting from the review of legislative acts. To readjust the arrangements now generally followed in the exercise of this authority, it will be necessary to distinguish three types of judicial review. First, there is a type which relates to the requirement that the proper procedure be followed in the enactment of laws, as for example, that a measure be approved by both houses, and that no irregularity vitiate the process of its consideration and enactment. This type of judicial review is recognized in most countries having written constitutions. Even where legislative supremacy prevails, as in France and Belgium, the courts are conceded to have the authority to interfere to correct procedural irregularities.

Second, there is a type of jurisdictional review. ${ }^{124}$ This type of review, so far as legislative acts are concerned, is an important phase of the government in all federal systems. Some umpire must be authorized to adjudicate the conflicts that may arise when the federal or local agencies interfere with the rights and functions of each other. ${ }^{125}$ It has been customary to confer upon the courts this umpire function. Whenever the provisions of the constitutions are relatively clear and the powers have been expressly and definitely divided between the national and local agencies, this jurisdictional type of review involves the courts in few controversies. The main purpose in constitutional revision, so far as this type of review is concerned, should be to make the division of powers between federal and local agencies as clear and exact as possible and to avoid such phrases as due process of law or equal

the country, to the advancement and welfare of all the provinces, and to the advancement and enlightenment of the people." Art. 67, $\$ 511$ and 16.

The Parliament of Australia has power "to make laws for the peace, and good government of the Commonwealth"; to grant bounties on the production or esport of goods; to regulate foreign corporations and trading or financial corporations; and to enact laws relating to matrimonial causes, invalid and old-age pensions and conciliation and arbitration. Art. 51 .

The Dominion government in Canada is granted authority "to make laws for the peace, order and good government of Canada in relation to all matters not coming within the classes of subjects by this act assigned exclusively to the legislatures of the provinces," also to enact laws relating to criminal Iaw and marriage and divorce. Art. 91.

The federal government of Switzerland has authority to enact regulations in regard to the exercise of trade and manufactures 35 well as with respect to the criminal law. Arts. 31 and 64.

124. It is not within the scope of this article to deal with this phase of the vort: of the Supreme Court wherein some of its most important and effective work has been accomplished.

125. For a defense of the application of the rule of federal legislative supremacy in a federal system of government, consult WILIMar E. RAPP.ARD, LE conimoLE DE IA coistrTU-

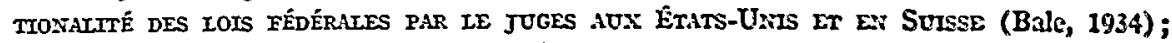
and for a brief analysis of judicial review of legislation in Canada and Australia, ses The Axterican Doctrine of Judicial Suprearicy (2d ed. 1932) 598, 578. 
protection of the laws which encourage the judges to engage in objectionable forms of legislation. This form of review of legislation operates to better advantage where, as in Switzerland, to the corrective of constitutional amendments there is added legislative authority to intervene when the public necessity or welfare requires, or where, as in Canada and Australia, vague and indefinite phrases are to a greater degree than in the United States omitted from the Constitution.

The third type of review is one in which the written fundamental law is interpreted or understood through vague, general terms such as due process of law and equal protection of the laws to give authority to the courts to check substantive acts of legislation and administration, thereby subjecting coördinate branches of the same government to judicial surveillance. It is the latter form of judicial review of legislation which was developed in the United States largely since 1885, and which has rendered the authority wielded by the courts the potent weapon that it is to protect vested interests. In any effort to change the existing system of review of legislation it will be necessary to recognize and trent somewhat differently the three types of judicial review as above described. Judging by the standards of effective and useful performance in the public interest, it appears that type one may well remain unchanged, type two will need to be retained with considerably limited scope for its application, and type three ought to be discontinued, or, if retained, should be made subject to reversal by subsequent legislative enactments, either by an ordinary majority vote or a two-thirds vote as in the case of the Presidential veto. And a method of amendment of the Constitution should be adopted which would come nearer to rendering effective the prevailing sentiment of the nation.

If such a convention were called and a new Constitution prepared, it would not be necessary to present an entirely new document to the voters for consideration. The amendments could be presented and voted upon separately so that in case of a disapproval of certain amendments the electors would not thereby register disapproval of the entire document. But desirable as these and other changes in the Constitution may be, it is not likely that a thorough revision of the Constitution will be made for some time to come. Has not the time come, however, to begin to consider and to prepare for the calling of such a Convention?

It is frequently contended that, when the justices interpret the Constitution so as to place undue limits on the authority of the federal government or of the states, the normal and expedient way to meet the situation is to take steps to amend the Constitution. But most of the proposals concerning the increase in federal powers can rather readily be defeated by the minority of the states which may not be interested or may find it to their advantage to oppose federal regulation. The 
failure to approve the Child Labor Amendment is indicative of the result which may be expected in the effort to enlarge federal authority through constitutional amendments. Nevertheless, sentiment is being crystallized in the direction of a few major amendments to remedy some serious defects in the distribution of powers between the federal and state governments as now interpreted by the courts.

The most important amendments which are being considered relate to the due process of law, the commerce, and the general welfare clauses of the Constitution. As a basis for discussion Dean Garrison of the Law School of the University of Wisconsin has proposed an amendment which provides that "Congress shall have power to promote the economic welfare of the United States by such laws as in its judgment are appropriate, and to delegate such a power in whole or in part to the states. Existing state powers are not affected by this article, except as Congress may occupy a particular field."120 Representative Wood, on behalf of various groups, presented for the consideration of Congress an amendment giving Congress power to enact uniform laws to regulate commerce, business, industry, finance, banking, insurance, manufactures, transportation, agriculture and the production of natural resources; ${ }^{192}$ and another, proposed by Senator Costigan, is designed to give Congress authority to regulate prices, wages, hours of labor and unfair practices which affect the general welfare of the United States. ${ }^{129}$

It is also proposed to take steps to authorize the federal government to enact and administer such measures as are in the interest of the general welfare. Bringing to public attention again a controversy agitated by constitutional lawyers for decades after the adoption of the Constitution, members of Congress contend that authority to pass laws to preserve and promote the general welfare was intended to be given to Congress in the first clause of Article 1, sec. 8, of the Constitution. Claiming that the intent of the Constitution was to confer this power, it is believed that Congress should assert its authority and that greater powers may thus be exercised by the federal government vithout a constitutional amendment. ${ }^{129}$ The language of the majority of the Court in the A.A.A. Case would seem to imply, however, that the Court as at present constituted proposes to determine when legislative acts properly come

126. (Jan. 29, 1936) NEW REPUBLIC, 329.

127. H. J. Res. No. 323, 74th Cong., 1st sess., June 12, 1935.

128. Resolution by Senator Costigan, S. J. Res. No. 3, 74th Cong., 1st ses3., Jan. 3, 1935.

129. Cf. Nullification of Acts of Congress, remarks of David J. Lewis in Houre of Representatives, 79 Cosig. Rec. 1390S (1935), and Lawsox, The Gevizus. Werfarse Clause: A Study of tae Power of Congress under the Constitution of the U:tred Stites (1934). 
within the scope of the general welfare and that only a constitutional amendment can accomplish the end desired.

In addition to the extreme difficulty of focusing public sentiment on any one of these proposals sufficiently to secure its adoption under the present system of minority control, a great difficulty appears in that, as long as the courts, applying the limitations of the Tenth Amendment and of the due process clause, retain authority to interpret these phrases and to declare acts of Congress void on the basis of these provisions, relatively little would be gained by the extraordinary effort and expense involved to secure the adoption of such amendments. The Canadian Constitution, for example, authorized the Dominion government to legislate for the good government of Canada or in the interest of the general welfare. The Canadian courts and the Privy Council, however, have interpreted this language so as to limit it to emergency conditions only, thereby emasculating the general welfare clause deliberately adopted to secure a type of central control lacking in the federal system of the United States. As long as the courts retain their present power of review of legislative acts, the attempts which are being made to amend the Constitution will, even if the necessary approval of Congress and the requisite number of states may be secured, prove to be only partial and ineffective expedients to secure more adequate control by the nation over its economic and social life.

For the time being, the only feasible methods, short of a thorough revision of the Constitution by means of a national constitutional convention - of enlarging the powers of the federal government to correspond to the nationalistic trends of the time along social and economic linesare either to bring such irresistible pressure to bear on the judges that they will find reasons to approve rather than to condemn legislation enacted for the public interest or the general welfare, or to place insuperable procedural obstacles in the way of the review of acts of Congress by the courts. To a considerable degree the carrying out of both of these methods belongs primarily to Congress and the President.

The recent decisions by the Supreme Court have brought a renewed interest in proposals to check the authority of the federal courts to review acts of Congress and to limit their jurisdiction both by legislative acts and constitutional amendments. These proposals include resolutions presented in Congress authorizing the Supreme Court to render advisory opinions, removing from the federal courts all authority to pass on the validity of acts of Congress, confining the review to acts to the Supreme Court, requiring more than a majority of the Court in passing on the validity of legislative acts, and restricting the jurisdiction of the federal courts so far as the consideration of the validity of legislative acts is 
concerned. ${ }^{130}$ A resolution proposed by Senator Norris provides that all judgments relating to the invalidity of laws because of conflicts with provisions of the Constitution must be concurred in by two-thirds of the members of the Court, and also that all such actions must be commenced within six months after the enactment. ${ }^{131}$ Even if it were within the range of possibility to enact laws or constitutional amendments to authorize the Supreme Court to render advisory opinions or to require a concurrence of at least two-thirds of the members of the court to declare a law void, only temporary and rather intermittent relief might be afforded from the decisions considered objectionable. But these and other constitutional amendments limiting the jurisdiction or procedure of the Supreme Court in dealing with questions relating to the validity of acts of Congress are not considered within the realm of probability.

Proposals are under consideration by Congress to restrict the jurisdiction of the inferior federal courts so far as the consideration of the validity of legislative acts is concerned and also to limit the appellate jurisdiction of the Supreme Court along similar lines. Such a limitation of jurisdiction is predicated upon the doctrine that the control over the jurisdiction of the lower federal courts is completely in the hands of Congress, and that according to the Constitution only such cases shall be appealed to the Supreme Court of the United States from the lower federal courts or from the state courts as Congress may from time to time ordain and direct.

It has been held from the time of the adoption of the Constitution that the inferior federal courts are dependent upon Congress for their existence and the powers they exercise. Congress has not hesitated to abolish inferior federal courts or to limit their jurisdiction. These courts have been prohibited from issuing injunctions relating to the assessment or the collection of a federal tax, though this limitation is proving ineffective and is now being vigorously contested; they have been deprived of jurisdiction under certain conditions to restrain the enforcement of orders of state utility commissions; and they have been prohibited, except through a specially constituted court of three judges, from enjoining actions of the Interstate Commerce Commission or of state officers claimed to be in violation of the federal Constitution. Speaking of the jurisdiction of the federal courts, Justice Sutherland commented as follows:

"Only the jurisdiction of the Supreme Court is derived directly from the Constitution. Every other court created by the general government derives its jurisdiction wholly from the authority of Congress. That body may give, withhold, or restrict such jurisdiction at its discretion, provided

130. See H. J. Res. Nos. 277, 317, 374, 74th Cong., 1st sess. (1934-35).

131. S. J. REs. No. 149, 74th Cong., 1st Sess., June 17, 1936. 
it be not extended beyond the boundaries fixed by the Constitution. The Constitution simply gives to the inferior courts the capacity to take jurisdiction in the enumerated cases, but it requires an act of Congress to confer it. And the jurisdiction, having been conferred, may, at the will of Congress, be taken away in whole or in part; and, if withdrawn without a saving clause, all pending cases, though cognizable when commenced, must fall."132

Concerning the appellate jurisdiction of the Supreme Court, Chief Justice Ellsworth said in 1796: "If Congress has provided no rule to regulate our proceedings, we cannot expect an appellate jurisdiction; and if the rule is provided, we cannot depart from it."133 This doctrine, reiterated a number of times, was reaffirmed in 1893 when it was announced that "this Court, therefore, as it has always held, can exercise no appellate jurisdiction, except in cases, and in the manner and form, defined and prescribed by Congress."134

Congress may without question regulate and limit the jurisdiction of the inferior federal courts and also may place restrictions upon the appellate jurisdiction of the Supreme Court. Carrying this doctrine to its logical conclusion, it would seem to follow that Congress may except from the jurisdiction of the lower federal courts the authority to review acts of Congress in so far as their validity or constitutionality is concerned and may also prevent appeal to the Supreme Court of such cases either from the lower federal courts or from the state courts. Congress accomplished this result in 1868 when it repealed a law authorizing appeals to the Supreme Court in order to prevent that tribunal from passing on the validity of certain Reconstruction Acts. As a result, the Supreme Court declined to accept jurisdiction in a case presented to it. ${ }^{196}$

It is, of course, possible that such a statute may be held void by the Supreme Court as an interference with the inherent powers of a court and with what is deemed as the necessary function of courts as established by Congress under the grant of authority to the judiciary by the Constitution. Indeed, it is now rather generally assumed that the requirements of due process of law, largely developed by judicial construction, would prevent the adoption of the proposed restrictions upon the exercise of judicial powers. ${ }^{136}$ Decisions by the Supreme Court to

132. Kline v. Burke Construction Company, 260 U. S. 226, 234 (1922).

133. Wiscart v. Dauchy, 3 Dall. 321,327 (U. S. 1796).

134. American Construction Company v. Jacksonville etc. Railway Company, 147 U. S. 372, 378 (1893). See Duncan v. The "Francis Wright," 105 U. S. 381, 386 (1881), in which it was noted that "authority to limit the jurisdiction necessarily carries with it authority to limit the use of the jurisdiction."

135. Ex parte McCardle, 7 Wall. 506 (U. S. 1868).

136. See reasoning of Chief Justice Taft in Truax v. Corrigan 257 U. S. 312 (1921) (holding void a state act which exempted certain parties from restraint by injunction whilo leaving others subject to such restraint, on the ground that it denied the equal protection of the laws). 
this effect, however, would run counter to the express language of the Constitution and it would be difficult to justify a reversal of the long accepted interpretation of the authority of Congress over the federal courts. The Supreme Court, may, however, as in the attempt to deny to the courts authority to issue injunctions, accept the doctrine of Congressional supremacy, but find ways of evading the effect of the statute. ${ }^{13 \pi}$

What can be done in the meantime, while public sentiment is in preparation for the adoption of amendments or the calling of a Constitutional Convention? Must the status quo remain without substantial change during what is apparently a rather long and indefinite period? The answer to this query need not be wholly discouraging. There are ways by which the power of the people acting through their authorized representatives may be rendered effective. In the first place, the deference to the decisions of courts involving the general attitude of acceptance of decisions invalidating acts and the refusal to move in contrary directions is an attitude which has been slowly developed and which is not expressly sanctioned by the fundamental law. When the justices choose the wrong road, as they did according to the best informed judgment in the minimum wage case $\mathrm{e}^{138}$ and in the application of the rule of Smyth $v$. Ames in rate regulation cases, ${ }^{139}$ it is possible, as the states have discovered, to continue to enforce more rational doctrines with relatively little interference by the federal courts. Neither Congress nor the Executive are obliged to accept the decisions of the courts as final and conclusive and beyond change so far as the political and economic effects of the decisions are concerned. ${ }^{130}$ The judges themselves insist that they do not declare acts of Congress invalid; they merely refuse to apply an act to the case in controversy. If the language is taken literally that the law remains as a law, its application merely being denied as between the parties before the court, the final declaration of invalidity may be a long deferred process. And why may not Congress, argued Madison, place an interpretation upon the Constitution which the courts and other departments should respect. In fact, Congress has placed such interpretations upon the Constitution, some of which have been the

137. See Miller v. Nut Margarine Co., 2S4 U. S. 498 (1932), in which the rule preseribad by REv. STAT. $\$ 3224$ (1878), 26 U. S. C. A. $\$ 154$ (1926), prohibiting suits in federal courts to restrain the assessment or collection of a tas was held, Stone and Brandeis, J. J., dissenting, not to be an absolute rule and to be inapplicable under "extraordinary and exceptional circumstancés." It was not dificult for federal judges to diseover such "extroordinary and exceptional circumstances" for the issuance of injunctions to retrain the enforcement of the tax provisions of the A.A.A.

138. Adkins v. Children's Hospital, 261 U. S. 525 (1923).

139. Chicago, Milwaukee \& St. Paul Ry. Co. v. Minnesota, 134 U. S. 418 (1890); Smyth v. Ames, 169 U. S. 466 (1898).

140. See Jackson's opinion on constitutionality of a national bank, 2 difssices Aid Papers of the Presments (1898) 581; Lincoln's views on Dred Scott Case, Lricolit Aid 
law of the land for many years. ${ }^{141}$ Conflicting interpretations persisted in by coördinate departments would necessitate more frequent reference of crucial constitutional questions of political or economic significance to the ultimate source of power-the people.

\section{VI}

Roger Pinto of the University of Paris in his recent monograph on the dissenting opinions of the Supreme Court ${ }^{142}$ contends that judicial review of legislation of the American type may have been useful and appropriate for a young and immature nation when the people were unwilling to trust themselves or their elected representatives. He then raises the query whether the American people have not grown up and whether they are not at the present time able to stand upon their own feet instead of continuing to depend in their economic and political conduct so largely upon the judgments of a few legal conservators. Cannot the spirit of uncertainty and distrust that surrounds our processes of legislation and execution be replaced by one of frank confidence and support even though we may realize that elected or appointed agents may make mistakes and that not all of their experiments may prove successful? May not the trial and error method which has been so characteristic of the growth of the common law, as well as of the doctrine of judicial review of legislation itself, now be applied in the grant to the primary political agencies - the legislative and executive departments-of a greater degree of freedom to enact and carry out policies deemed in the public interest?

There are many who, as in the formative period of American political institutions, desire a governmental system of checks and balances, the continuance and extension of the aristocracy of the robe, and the assurance that the property and contract rights will be preserved by what the Jeffersonian Republicans called the "check" department of the government. But those who object to the authority wielded by the courts in the exercise of judicial review usually accept the doctrine of review of legislative acts as inevitable in the American system of government and seek what Professor Lambert calls "palliatives" for the unwise and reactionary decisions of judges. ${ }^{143}$ Have we not discovered how weak and inapposite these palliatives are, such as the proposals to remedy

Dougras Debates (1895) 29, 30, and First Inaugural Address; contention of Theodoro Roosevelt that "it is the people and not the judges, who are entitled to say what their Constitution means," from Introduction to RaNSOM, MajorITY RULE AND THE JUdiciary (1912) 3.

141. See decision of Congress on the removal power of the President, approved in Myers v. United States, 272 U. S. 52 (1925).

142. DES JUGES QUT NE GOUVERNEMENT PAS: OPINTONS DISSIDENTES A LA COUR SUPREMTE DES ÉTATS-UNIS (1900-1933) 1934.

143. Cf. Le Gouvernestent des Juges (1921) c. X. 
the defects of judicial review of legislation by educating the judges in social and economic affairs, or by requiring more than a majority for the decision of controversial cases, or by permitting a recall of judges or of judicial decisions? Has not the time come to recognize frankly that with all the advantages of judicial review, so far as the acts of coördinate branches of government are concerned, and, to a limited degree, for the review of the acts of subordinate divisions of the federal system in accordance with vague and indefinite terms, a method was adopted in the adjustment of legal relations in the United States which leads only to political paralysis? And has it not become apparent that the adoption of legislative supremacy will offer the only consistent and permanent remedy for some of the foremost defects in the administration of federal government in the United States?

Steps leading in the direction of legislative supremacy rould, of course, have to be taken gradually and with considerable caution so as not to disrupt too drastically the delicate system of controls which the judges have gathered unto themselves. But the fears which special interests have conjured up against the exercise of greater legislative powers, are to a considerable extent illusory. Legislatures do not normally set about to destroy existing property or vested rights. They do not interfere with the court's ordinary interpretation and application of the laws, if the judiciary does not enter the realm of politics and legislation. Where the representative system with legislative supremacy prevails, the operations of government are carried out much the same as they are in countries with judicial supremacy. It is only when grave political issues are at stake that questions of political supremacy play a prominent part in public discussions. And it is with respect to such issues that legislative supremacy involves a greater degree of freedom in carrying out policies deemed vital to the public welfare and judicial supremacy is more likely to be concerned with the preservation of private interests and the protection of property rights.

It is contended that according to such a view the Constitution would no longer be the supreme law of the land as provided by its language. The issue, however, may be more accurately stated as to whether it is a lawyer's interpretation of the Constitution or the people's interpretation that is to prevail. ${ }^{144}$ In most foreign countries the rule is adopted that the guardianship of the constitution belongs to the legislature, and, subject to a reversal by popular referendum or the election of a new

144. "I contend that the people, in the nature of things must be better judges of what is the preponderant opinion than the courts, and that the courts should not be allowed to reverse the political philosophy of the people." Theodore Roosevelt, Tise Right of the People to Rule (March 23, 1912) Ourroor 620. 
assembly, the legislature determines the limits of its own authority and exercises control over the other departments of government. The legislature not only exercises ordinary legislative authority, but is recognized as possessing constituent powers to a limited extent. Where this rule is accepted, a written constitution is regarded mainly as a document comprising groups of political laws which the political departments are both by reason of propriety and convenience empowered to interpret, except when reversed by constitutional amendments. The well recognized dictum of American Judges that there are certain questions of a political nature which the courts ought not to undertake to determine, and which should be settled by the legislative and executive departments of government, is extended so as to include practically all of the provisions of the Constitution. The prescriptions of the Constitution, not being considered laws in the ordinary sense as understood by judges in interpreting and applying their provisions, cannot form the basis of a contention or case before a court. A controversy regarding the meaning of a constitutional provision is simply not a justiciable controversy. The basic hypotheses, therefore, on which the American constitutional structure is founded, that constitutions are laws in the ordinary significance of that term, and that a case or controversy involving an alleged conflict between a constitutional provision and a statute is necessarily subject to judicial cognizance, are in those other countries repudiated as legally unsound and politically impracticable. ${ }^{145}$ The courts in all but a few foreign countries are either denied the authority to review legislative acts or, when such authority is conceded as belonging to the courts, it is so seldom exercised as to have relatively slight effect upon the practical operation of the government.

In a prophetic vein Richard Henry Lee, in arguing against the adoption of the federal Constitution, objected to the amending clause on the grounds that it would make changes extremely difficult. Possibly foreseeing the interpretation of the Constitution by an appointive judiciary, he made the following prediction:

"While power is in the hands of the people, or democratic part of the community, more especially as at present, it is easy, according to the general course of human affairs, for the few influential men in the community, to obtain conventions, alterations in government, and to persuade the common people that they may change for the better, and to get from them a part of the power: But when power is once transferred from the many to the few, all changes become extremely difficult; the government, in this case, being beneficial to the few, they will be exceedingly artful and adroit in preventing any measures which may lead to a change; and

145. Cf. Some Phases of the Theory and Practice of Judicial Review of Legislation in Foreign Countries (1930) 24 Aar. PoL. Scr. Rev. 583. 
nothing will produce it, but great exertions and severe struggles on the part of the common people. Every man of reflection must see, that the change now proposed, is a transfer of power from the many to the few, and the probability is, the artful and ever active aristocracy, will prevent all peaceful measures for changes, unless when they shall discover some favorable moment to increase their own influence. ${ }^{1100}$

And it is obvious that, the change of base to which Iee referred having been made, the way toward a restoration of the powers of the people appears to be lined with innumerable obstructions.

But urgent as is the need for constitutional reform along many lines and difficult as it appears to remove the judges from their intrenched position of supremacy in the American federal system, the issue of judicial review of legislation must be resolved in favor of the establishment of popular control over major political issues and of the removal from judicial control of controversies regarding the public powers of government; and this issue must be settled before any effective constitutional reform along other essential lines can be accomplished. The decisions of the Supreme Court in the "Hot Oil," Railroad Pension, N.R. A., and A.A.A. Cases, and the threat of a national calamity by a possible adverse decision in the Gold Clause Cases as well as the disastrous results which may follow from impending decisions of scarcely less significance, raise more insistently than at any other time in the nation's history the question as to the desirability of the present system of judicial review of legislation. Among the various devices to check judicial review of legislation and to permit public sentiment to express itself more freely, the one which had the greatest appeal at the time President Theodore Roosevelt made judicial review one of the major political issues, was the plan of securing liberal minded judges upon the bench. The inadequacy of such a plan is apparent. We are thus brought face to face with the real challenge to American statesmen of the twentieth century, namely, whether we shall take steps to overcome the extreme rigidity of constitutional law by adopting a series of constitutional amendments which will carry out the purpose and intent of the constitutional development of more than a century to make the United States in reality a nation, and whether we shall begin an agitation in favor of a constitutional convention with the object of securing a thorough revision of the federal fundamental law. In the meantime, the coördinate branches of the government may be prevailed upon to exercise some of the undoubted authority which they possess under the Constitution to foster and preserve government by the people rather than to accept a judicial supremacy developed largely through judicial construction often prompted by the urgent de-

146. From Letters of a Federal Farner (1930) in Ford, Pasminers o:i ral Co:sistruTION (1888) 317, 318. 
mands of interested groups and applied in such a way as to protect such groups.

The statesmen of 1787 to 1789 faced the issue and did not hesitate when necessary, to resort to revolutionary methods to change the fundamental law to meet the conditions of the time. Similarly, the statesmen of 1861 to 1865 refused to permit the Constitution to stand as a barrier in the way of carrying out the well matured sentiment and policies of the nation. Will the statesmen of the twentieth century fail to take the necessary steps to adjust their government to the prevailing conditions of economic and political life? Will national policies and progress be confined permanently within the express restrictions and the judge-made limits of a written Constitution prepared essentially to suit eighteenth century conditions, or will both the Constitution and its judicial gloss be changed, as Jefferson and Lincoln insisted they should, to accord with the progress of the life of the people? 